\title{
Physicochemical and sensory properties of milk supplemented with dispersible nanopowdered oyster shell during storage
}

\author{
Y. K. Lee, ${ }^{*}$ S. I. Ahn, ${ }^{*}$ Y. H. Chang, $\dagger^{1}$ and H. S. Kwak ${ }^{* 1}$ \\ *Department of Food Science and Technology, Sejong University, Seoul 143-747, Korea \\ †Department of Food and Nutrition, Kyung Hee University, Seoul 130-701, Korea
}

\begin{abstract}
The current study was carried out to investigate the dispersibility of powdered oyster shell (POS), nanopowdered oyster shell (NPOS), and Zn-activated nanopowdered oyster shell (Zn-NPOS) in milk and to determine effects of adding oyster shell on the physicochemical and sensory properties of milk during storage at $4{ }^{\circ} \mathrm{C}$ for 16 d. To ensure dispersibility, 10\% (wt/vol) oyster shell was added to distilled water and stirred at $800 \mathrm{rpm}$ for $2 \mathrm{~h}$, and then the emulsifier $0.5 \%$ polyglycerol monostearate (PGMS) was added and stirred continually for $24 \mathrm{~h}$. The particle sizes of POS, NPOS, and Zn-NPOS were $180 \mu \mathrm{m}, 389 \mathrm{~nm}$, and $257 \mathrm{~nm}$, respectively. The $\mathrm{pH}$ values of all milk samples ranged from 6.62 to 6.88 during storage, and the zeta-potential of milks with NPOS and Zn-NPOS added were more stable than that of milk with POS in low concentrations $(0.5$ and $1.0 \%$, $\mathrm{vol} / \mathrm{vol}$ ) during storage. The $\mathrm{L}$ and a color values of the milks were not significantly influenced by treatment; however, the $\mathrm{b}$ value (yellow-blue color) significantly increased during storage after adding POS, NPOS, or Zn-NPOS. Sensory analysis revealed that sedimentation score significantly increased with POS-supplemented milk, but the NPOS- and Zn-NPOS-supplemented milks did not show sedimentation until after $8 \mathrm{~d}$ of storage. Based on the data obtained, we conclude that dispersible nanosized oyster shell at concentrations of 0.5 and $1.0 \%$ (vol/vol) could be supplemented to milk without significant adverse effects on physicochemical and sensory properties.
\end{abstract}

Key words: nanopowdered oyster shell, sensory properties, calcium-added milk

\section{INTRODUCTION}

Calcium is an important mineral for human body that aids in construction of bone and is required for

\footnotetext{
Received November 14, 2014.

Accepted May 11, 2015.

${ }^{1}$ Corresponding authors: kwakhs@sejong.ac.kr and yhchang@khu. ac.kr
}

normal growth, maintenance, and development of the skeleton (Bonjour and Rizzoli, 2001; Rizzoli, 2008); therefore, dietary calcium intake is necessary. According to the Institute of Medicine of the United States, adults from 19 to $50 \mathrm{yr}$ old are advised to take 1,000 mg of calcium daily (Institute of Medicine, 2010), and the European Parliament recommend that adults of any age consume $800 \mathrm{mg} / \mathrm{d}$ (European Commission, 2008). However, dietary calcium intake has never been sufficient, and dietary intervention through the supplementation of calcium in foods is recommended to meet proper requirements. Milk is as an excellent source of calcium, considering the absorption of calcium and its bioavailability in milk (Wong and Lacroix, 1980; Kansal and Chaudhary, 1982). The calcium contents of market milk range from 100 to $120 \mathrm{mg} / \mathrm{mL}$ (Yoo et al., 2013); however, the calcium content of milk is insufficient for optimal growth in children and does not meet the higher calcium requirements of postmenopausal women. Recently, several studies have examined milk supplemented with calcium (Kruger et al., 2006; Singh et al., 2007; On-Nom et al., 2012; Kaushik et al., 2014).

Therefore, it is necessary to supplement milk with a calcium source, such as oyster shell, eggshell, or pearl. Among these, oyster shell could be a good, natural source of calcium: it contains about $37 \%$ calcium; is widely available, inexpensive, and high quality; and it could be added to milk without altering flavoring or taste (Ajakaiya and Leeson, 1997). The beneficial effect of oyster shell has been confirmed in bone tissue engineering (Yang et al., 2011). Oyster shell has some other positive effects - it is bioactive and biocompatible with materials of bone grafting (Lamghari et al., 1999; Duplat et al., 2007). It contains other nutrients, such as Zn, P, and amino acids (Wheeler et al., 1988). Surprisingly, this valuable calcium source is currently considered a waste product after oyster meat is consumed. Oyster shell is disposed of in landfills, adding to environmental pollution. The use of oyster shell in the food industry has been limited by the insolubility of oyster shell in water. Certain emulsifiers can be used to disperse oyster shell powder (Park et al., 2001; Seo et al., 2011). However, oyster shell particles are large and 
hard, and the commercially available micro-particle products have low bioavailability and solubility (Huang et al., 2009). Nanotechnology could be an effective tool to improve the bioavailability of oyster shell.

Nanosizing is a relatively new and emerging technique used in food industries to improve stability and solubility (Rasenack and Muller, 2004). It has the potential to enhance foods in various ways, such as increasing the bioavailability of nanonutrients in foods. The increase of bioavailability of calcium through nanosizing has been recently reported in several studies (Park et al., 2008; Hilty et al., 2011; Seo et al., 2011; Ahn et al., 2013). We recently observed in an (unpublished) animal study that the bioavailability of nanopowdered oyster shell (NPOS) and zinc-activated NPOS (Zn-NPOS) increased to 29.14 and $60.76 \%$, respectively, over that of powdered oyster shell (POS; 10\%). However, as far as we are aware, no studies have reported the production and physicochemical and sensory properties of milk supplemented with NPOS or Zn-NPOS. Therefore, the aim of this study was to investigate milk supplemented with dispersible NPOS and Zn-NPOS, and to determine the effects of this addition on the physicochemical and sensory properties of milk.

\section{MATERIALS AND METHODS}

\section{Materials}

Powdered oyster shell was obtained from Haesung Co. (Tongyeong, Korea), and NPOS and Zn-NPOS made by a dry milling method at room temperature were purchased from Apexcel Co. (Pohang, Korea). Market milk (3.8\% milk fat) was purchased from Seoul Dairy Co-op. (Ahnsan, Korea). The emulsifiers polyglycerol monostearate [PGMS; hydrophile-lipophile balance (HLB) $=15.8]$, polyoxyethylene sorbitanmonolaurate $(\mathbf{P S M L}$; HLB 16.7), decaglycerine monooleate (DGML; HLB 14.5), and polyglycerol fatty acid ester (PGFE; HLB 13) were supplied by Il-Sin Co. Ltd. (Seoul, Korea). All other chemicals were purchased from Sigma Chemical Co. (St Louis, MO).

\section{Particle Size Analysis}

Size and morphological characteristics of POS, NPOS, and Zn-NPOS were observed using field-emission electron microscopy (FE-SEM, S-4300, Hitachi, Tokyo, Japan). The samples were spread on the surface of a stub with double sticky carbon tape. The samples were sputtered with white gold for $120 \mathrm{~s}$ (Ion sputter, E-1030, Hitachi, Tokyo, Japan) and then examined by scanning electron microscope operating at an accelerating voltage of $15.0 \mathrm{kV}$.
To analyze particle size, $0.1 \mathrm{~g}$ of NPOS or Zn-NPOS was dispersed into $10 \mathrm{~mL}$ of ethanol. The suspension was then treated by a Branson 3210 ultrasonic system (Triad Scientific, Manasquan, NJ) for 30 min and kept at room temperature for $10 \mathrm{~min}$. After pretreatment, the suspension was poured into a cuvette and the particle size was determined using a particle size analyzer (Delsa Nano C, Beckman Coulter Inc., Fullerton, CA) at $25^{\circ} \mathrm{C}$ and $160^{\circ}$ scattering angles. The particle size of the POS was determined by using another instrument (Mastersizer-2000, Malvern Instruments Ltd., Worcestershire, UK) at $25^{\circ} \mathrm{C}$ and $90^{\circ}$ scattering angles. Each measurement was done in triplicate and the result was the mean value.

\section{Optimization of Dispersible Oyster Shell}

To disperse the POS, NPOS, and Zn-NPOS, $10 \%$ (wt/vol) samples were stirred in water for $2 \mathrm{~h}$ at 800 rpm at room temperature, and then different emulsifiers (PGMS, PSML, DGML, and PGFE) were added to the oyster shell solutions. The suspensions were stirred at room temperature for different mixing times $(0,12$, 24 , and $36 \mathrm{~h}$ ) at a constant mixing speed of $800 \mathrm{rpm}$. After stirring, the stability of the dispersed samples was measured by zeta-potential (Delsa Nano C, Beckman Coulter Inc.). All samples were measured 3 times at a fixed temperature $\left(25^{\circ} \mathrm{C}\right)$ and angle $\left(15^{\circ}\right)$. Zetapotential was measured at 5 points of the cell position $(0.7,0.35,0,-0.35$, and -0.7$)$.

\section{Manufacture of Milk Supplemented with Dispersible Oyster Shell}

Milk supplemented with POS, NPOS, and Zn-POS was produced by the procedure of Seo et al. (2011) with slight modifications. The POS, NPOS, or Zn-NPOS were sterilized at $121^{\circ} \mathrm{C}$ for $15 \mathrm{~min}$ by autoclave (JSAC100, JS Research Inc., GongJu, Korea) and added to pasteurized market milk packed in cartons $(200 \mathrm{~mL})$ at different concentrations $(0.5,1.0,1.5$, and $2.0 \%)$ using a disposable syringe (Korea Vaccine Co. Ltd., Ansan, Korea) and stirred with a vortex mixer (Vortex Genie 2, Scientific Industries, Bohemia, NY) for 5 min. The milks with dispersible oyster shell were then stored at $4^{\circ} \mathrm{C}$ for $0,4,8,12$, and $16 \mathrm{~d}$ for analyses. The samples were made in triplicate.

\section{$\mathrm{pH}$ and Mineral Contents}

The $\mathrm{pH}$ values of milk samples supplemented with POS, NPOS, and Zn-NPOS were measured using a glass electrode pH meter (model 900A, Orion, Madison, WI) 
at $4^{\circ} \mathrm{C}$. To measure mineral contents, samples $(0.5 \mathrm{~mL})$ were dissolved in $5 \mathrm{~mL}$ of nitric acid, $50 \mu \mathrm{L}$ of hydrogen peroxide was added, and the solution was heated at $110^{\circ} \mathrm{C}$ for $8 \mathrm{~h}$. The solution was then kept at room temperature for $10 \mathrm{~min}$. After adding $10 \mathrm{~mL}$ of grade 3 pure distilled water to each sample, concentrations of $\mathrm{Ca}, \mathrm{P}$, and $\mathrm{Zn}$ were determined using inductively coupled plasma optical emission spectroscopy (ICPOES, Optima 7300 DV, PerkinElmer Inc., Waltham, MA). All samples were measured in triplicate.

\section{Color Measurement}

Color values of the milk samples supplemented with POS, NPOS, and Zn-NPOS were measured using a colorimeter (CR210, Minolta, Tokyo, Japan) after calibrating its original value with a standard plate (X $=97.83, \mathrm{Y}=81.58, \mathrm{Z}=91.51)$. Measured $\mathrm{L}$, a, and $\mathrm{b}$ values were used as indicators of lightness to darkness, redness to greenness, and yellowness to blueness, respectively.

\section{Sensory Analysis}

Sensory evaluation of the milk samples supplemented with POS, NPOS, or Zn-NPOS was performed by 10 judges (aged from 25 to $33 \mathrm{yr}$ and familiar with dairy products) selected from graduate students of the Department of Food Science and Technology in Sejong University (Seoul, Korea). Three 1-h training sessions were held for development of attributes, definitions, and panel training, respectively. At the end of the session, sensory attributes were established: 1 each for appearance, flavor, and taste. Sedimentation (appearance) was investigated using commercial milk. Commercial milk not having sediment at the bottom was used as the standard for evaluating sedimentation in each milk sample. Sedimentation was defined as particles settling to the bottom of a transparent glass (Ali et al., 2006). For flavor, mushroom compost $(1 \mathrm{~g})$ in water $(20 \mathrm{~mL})$ was used as the standard for earthy flavor (Abbott et al., 1991). For taste, bitterness was defined as the fundamental taste sensation elicited by caffeine or quinine (Drake, 2007). Standards used to define these taste descriptors were presented during training and sensory evaluation.

The attributes developed by judges were scored using 5 -point scales, from 1 (no presence of the attribute) to 5 (maximum value of the attribute). Samples were stored at $7^{\circ} \mathrm{C}$ before assessment. In each session, the order of assessment of the sample was randomized and the scores of each sample were averaged over all assessors. The sensory evaluation was performed in duplicate.

\section{Statistical Analysis}

Analysis of variance and Duncan's multiple range tests were performed to analyze differences between groups. Data were expressed as mean $\pm \mathrm{SD}$ and the statistical significance was set at $P<0.05$. All statistical analyses were done using SAS 9.0 (SAS Institute, 2001), and graphical representations were performed using Sigmaplot 10.0 (Systat Software Inc., San Jose, $\mathrm{CA})$.

\section{RESULT AND DISCUSSION}

\section{Particle Size Analysis}

The morphology of all samples was observed by scanning electron microscopy as shown in Figure 1. The images show NPOS and Zn-NPOS as globular and congregated particles (Figure $1 \mathrm{~B}$ and $1 \mathrm{C}$ ). However, POS was characterized by irregularly shaped particles (Figure 1A). The average sizes of POS, NPOS, and ZnNPOS were $180 \mu \mathrm{m}, 389 \mathrm{~nm}$, and $257 \mathrm{~nm}$, respectively.

\section{Optimization of Dispersible Oyster Shell}

The most common method of measuring stability in food is a storage test, such as zeta-potential (Kwak, 2014). Assessment of zeta-potential is an important method to measure the stability of suspensions (Karraker and Radke, 2002) and investigate the dispersibility of particles (Xu, 2002; Delgado et al., 2005). The zeta-potential of dispersibility measured to optimize $10 \%$ (wt/vol) POS, NPOS, and Zn-NPOS in water for stability is presented in Figures 2 and 3. The stability of all samples emulsified with PGMS (HLB 15.8) increased significantly more than that of samples emulsified with the other emulsifiers (PSML, DGML, and PGFE; $P<0.05$; Figure 2). The zeta-potentials of suspensions of NPOS and Zn-NPOS with PGMS were -17.2 and $-15.9 \mathrm{mV}$, respectively. Nakahara et al. (1978) reported that $\mathrm{CaCO}_{3}$ was stable in hydrophilic emulsifier. In this study, the samples emulsified with the higher hydrophilic emulsifiers, PGMS (HLB 15.8) and PSML (HLB 16.7), showed higher stability because the surfactant in the outer aqueous phase was effective to ensure stability (Pays et al., 2001). Furthermore, we found in this study that PGMS had the highest stability for dispersibility.

After identifying the best emulsifier, the optimum concentration of PGMS was determined by zeta-potential using various concentrations during $2 \mathrm{~h}$ at $800 \mathrm{rpm}$ in room temperature (data not shown). Our results showed that the zeta-potential of all dispersions were significantly increased until $0.5 \%$ (wt/vol) and were 

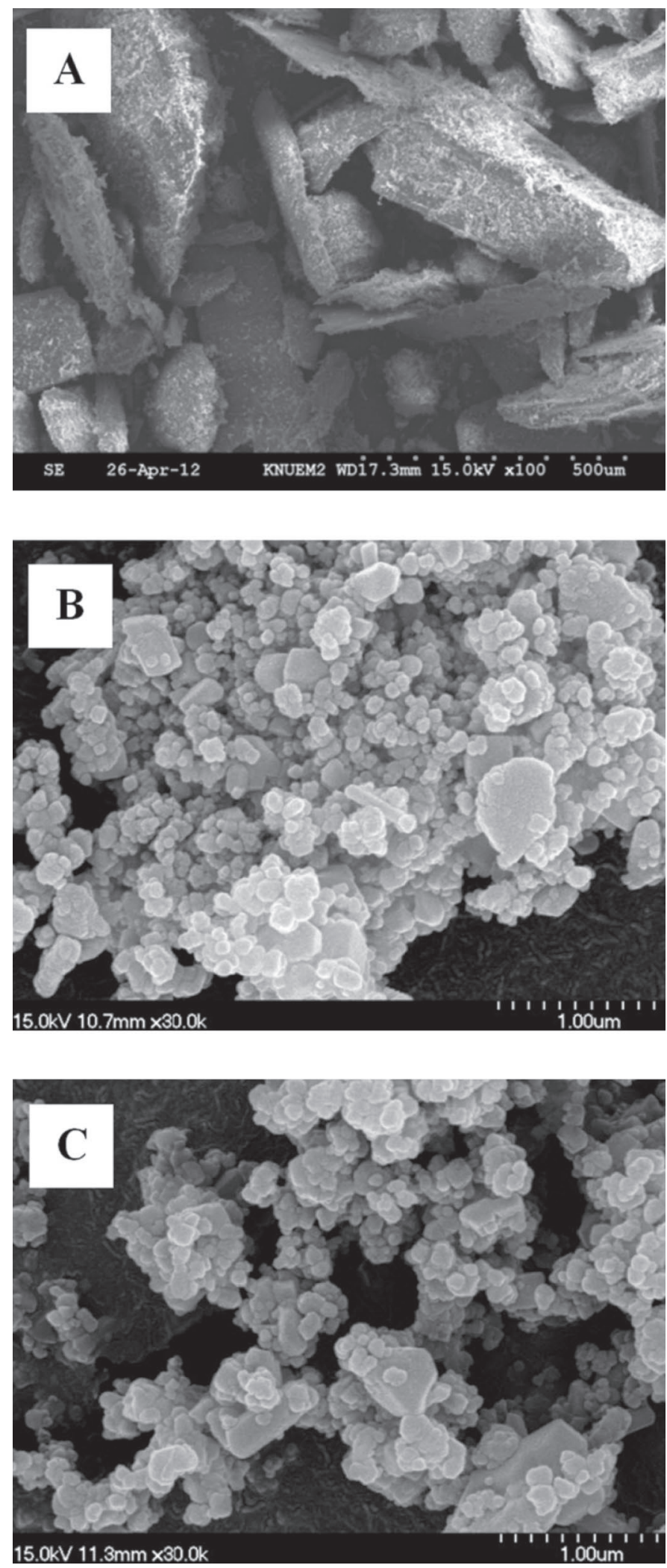

Figure 1. Scanning electron microphotographs and particle size of nanopowdered oyster shell: (A) powdered oyster shell, (B) nanopowdered oyster shell, and (C) Zn-activated nanopowdered oyster shell.

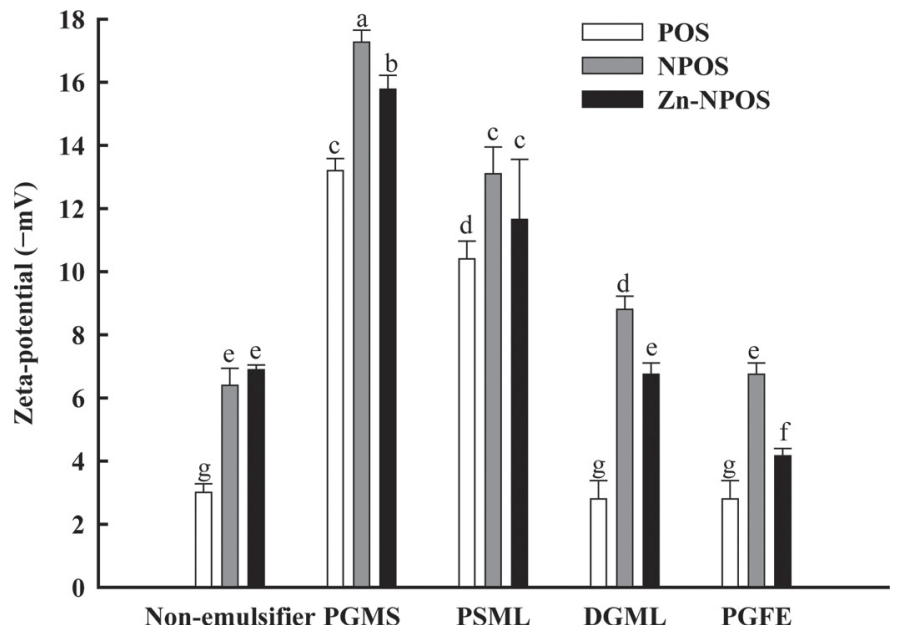

Figure 2. Effects of $0.5 \%$ (wt/vol) emulsifier [none, polyglycerol monostearate (PGMS), polyoxyethylene sorbitan monolaurate (PSML), decaglycerine monoleate (DGML), polyglycerol fatty acid ester (PGFE)] on dispersible stability as evaluated by zeta-potential of nanopowdered oyster shell during $24 \mathrm{~h}$. POS = powdered oyster shell, NPOS = nanopowdered oyster shell, Zn-NPOS = Zn-activated nanopowdered oyster shell. Bars with different letters differ significantly at $P<0.05$ by Duncan's multiple range test; error bars indicate standard deviations.

similar thereafter. Therefore, the optimum concentration of PGMS was $0.5 \%$ (wt/vol).

After optimizing concentration, we determined the optimal mixing time for dispersible powder samples at room temperature and $800 \mathrm{rpm}$, as shown in Figure 3. The zeta-potential of all dispersions was significantly and proportionally increased until $24 \mathrm{~h}(P<0.05)$ and was similar thereafter. The zeta-potentials of POS, NPOS, and Zn-NPOS were $-13.1,-17.2$, and -15.9 $\mathrm{mV}$, respectively, in $0.5 \%$ PGMS after $24 \mathrm{~h}$ of mixing. Therefore, we concluded that optimum conditions for dispersible POS, NPOS, and Zn-NPOS were $0.5 \%$ (vol/ vol) PGMS and a 24-h mixing time.

\section{pH}

Changes in the $\mathrm{pH}$ values of the milk samples supplemented with various concentrations of POS, NPOS, and Zn-NPOS for $16 \mathrm{~d}$ at $4^{\circ} \mathrm{C}$ are shown in Table 1. The $\mathrm{pH}$ of all samples decreased significantly during 16 $\mathrm{d}$ of storage $(P<0.05)$. Initially, $\mathrm{pH}$ values decreased proportionally with increasing concentrations $(0.5,1.0$, 1.5 , and $2.0 \%$ ) of supplemented samples and this trend continued to the final period of storage. The $\mathrm{pH}$ of supplemented milks ranged from 6.88 to 6.62 , which is almost within the normal range of market milk. The $\mathrm{pH}$ values of POS, NPOS, and Zn-NPOS were 9.97, 9.34 , and 9.43 , respectively. The $\mathrm{pH}$ of the control milk ranged from 6.80 to 6.65 during storage. The $\mathrm{pH}$ values 


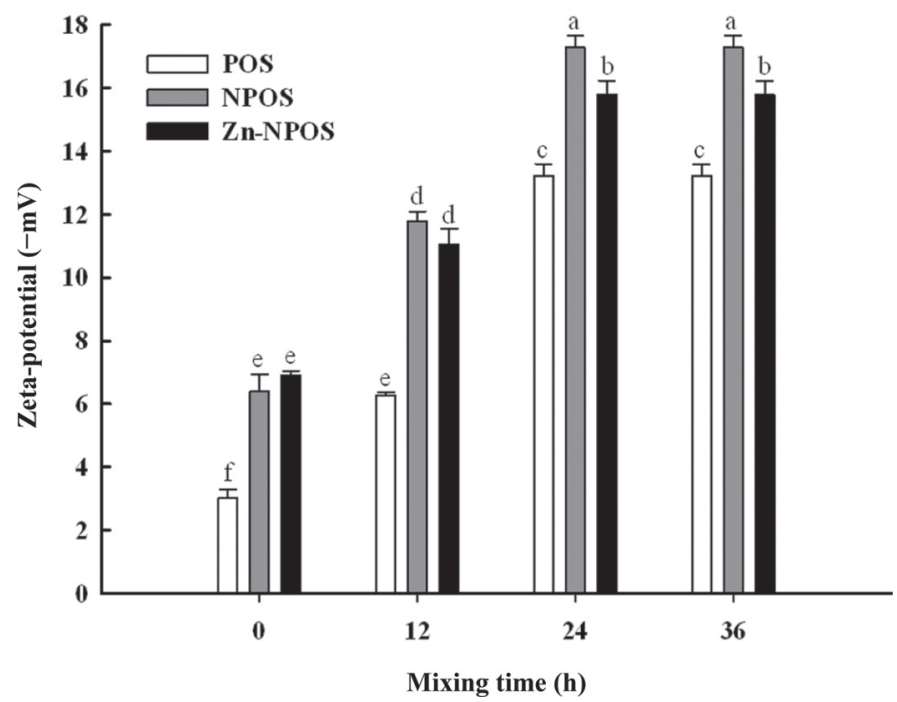

Figure 3. Effects of mixing time on dispersible stability as evaluated by zeta-potential of nanopowdered oyster shell emulsified with $0.5 \%(\mathrm{wt} / \mathrm{vol}$ ) polyglycerol monostearate. POS = powdered oyster shell, NPOS = nanopowdered oyster shell, Zn-NPOS = Zn-activated nanopowdered oyster shell. Bars with different letters differ significantly at $P<0.05$ by Duncan's multiple range test; error bars indicate standard deviations.

for all milk samples were nearly constant during 16-d storage and similar to that of fresh milk (Lee et al., 2006). These results indicated that the supplementation of POS, NPOS, and Zn-NPOS to milk did not adversely affect the $\mathrm{pH}$ of milk during $16 \mathrm{~d}$ of storage.

\section{Calcium Content}

The concentration of calcium in the milk samples was determined as shown in Table 2. The calcium content of the control was $108 \mathrm{mg} / 100 \mathrm{~mL}$. The total calcium contents of market milk range from 100 to 120 $\mathrm{mg} / 100 \mathrm{~mL}$ (Yoo et al., 2013). The calcium contents of POS-, NPOS-, and Zn-NPOS-supplemented milks did not differ significantly $16 \mathrm{~d}$ of storage time $(P<0.05)$, whereas the calcium contents in milks significantly increased with an increase in the concentrations of POS, NPOS, Zn-NPOS.

\section{Dispersibility of Oyster Shell Powder in Milk}

The dispersibility of POS-, NPOS-, and Zn-NPOSsupplemented milks during storage at $4^{\circ} \mathrm{C}$ for $16 \mathrm{~d}$ is shown in Figure 4. The dispersibility of the milk samples was evaluated by zeta-potential. Theoretically, when the zeta-potential value of dispersion becomes closer to zero, the dispersion becomes electrically unstable. Zeta-potential values showed a trend to decrease with increasing concentrations of calcium in the milk samples. The milks with NPOS and Zn-NPOS were more stable than those with POS on $d 0$. The zetapotentials of milks with the lower concentration $(0.5 \%$, $\mathrm{vol} / \mathrm{vol}$ ) of NPOS and Zn-NPOS were -42 and -41 $\mathrm{mV}$, respectively; however, the zeta-potential of milk with POS added at $0.5 \%$ decreased to only $15 \mathrm{mV}$. The zeta-potential values of all milk samples decreased with increasing concentrations of POS, NPOS, and ZnNPOS. In general, dispersions with high zeta-potentials $(> \pm 30 \mathrm{mV})$ are electrically stabilized, whereas those with low-zeta potentials $(< \pm 30 \mathrm{mV})$ are unstable and likely to rapidly produce coagulates or flocculates (Hanaor et al., 2012). According to Sahoo et al. (2002), the zeta-potential values for nanoparticles prepared with low concentrations of polyvinyl alcohol were greater than those prepared with high concentrations of polyvinyl alcohol. The zeta-potential of the fat globules of the regular milk was found to be $-18 \mathrm{mV}$ (Wade

Table 1. Change in $\mathrm{pH}($ mean $\pm \mathrm{SD})$ of milk supplemented with dispersible nanopowdered oyster shell and stored at $4^{\circ} \mathrm{C}$ for $16 \mathrm{~d}$

\begin{tabular}{|c|c|c|c|c|c|}
\hline \multirow{2}{*}{$\begin{array}{l}\text { Treatment }^{2} \\
(\%, \mathrm{wt} / \mathrm{vol})\end{array}$} & \multicolumn{5}{|c|}{ Storage time } \\
\hline & d 0 & $\mathrm{~d} 4$ & d 8 & d 12 & d 16 \\
\hline Control & $6.81 \pm 0.02^{\mathrm{a}}$ & $6.81 \pm 0.02^{\mathrm{a}}$ & $6.80 \pm 0.04^{\mathrm{a}}$ & $6.79 \pm 0.01^{\mathrm{b}}$ & $6.79 \pm 0.09^{\mathrm{b}}$ \\
\hline POS (0.5) & $6.80 \pm 0.09^{\mathrm{a}}$ & $6.81 \pm 0.05^{\mathrm{a}}$ & $6.81 \pm 0.08^{\mathrm{a}}$ & $6.79 \pm 0.05^{\mathrm{b}}$ & $6.79 \pm 0.01^{\mathrm{b}}$ \\
\hline POS (1.0) & $6.80 \pm 0.02^{\mathrm{a}}$ & $6.81 \pm 0.07^{\mathrm{a}}$ & $6.80 \pm 0.04^{\mathrm{a}}$ & $6.78 \pm 0.09^{\mathrm{b}}$ & $6.79 \pm 0.00^{\mathrm{b}}$ \\
\hline POS (1.5) & $6.80 \pm 0.01^{\mathrm{a}}$ & $6.81 \pm 0.05^{\mathrm{a}}$ & $6.80 \pm 0.03^{\mathrm{a}}$ & $6.78 \pm 0.03^{\mathrm{b}}$ & $6.79 \pm 0.01^{\mathrm{b}}$ \\
\hline POS (2.0) & $6.80 \pm 0.05^{\mathrm{a}}$ & $6.81 \pm 0.06^{\mathrm{a}}$ & $6.80 \pm 0.04^{\mathrm{a}}$ & $6.80 \pm 0.04^{\mathrm{b}}$ & $6.78 \pm 0.03^{\mathrm{b}}$ \\
\hline NPOS $(0.5)$ & $6.81 \pm 0.03^{\mathrm{a}}$ & $6.81 \pm 0.09^{\mathrm{a}}$ & $6.80 \pm 0.04^{\mathrm{a}}$ & $6.78 \pm 0.07^{\mathrm{b}}$ & $6.79 \pm 0.08^{\mathrm{b}}$ \\
\hline NPOS (1.0) & $6.80 \pm 0.02^{\mathrm{a}}$ & $6.81 \pm 0.08^{\mathrm{a}}$ & $6.80 \pm 0.09^{\mathrm{a}}$ & $6.78 \pm 0.08^{\mathrm{b}}$ & $6.79 \pm 0.07^{\mathrm{b}}$ \\
\hline NPOS (1.5) & $6.80 \pm 0.08^{\mathrm{a}}$ & $6.81 \pm 0.08^{\mathrm{a}}$ & $6.80 \pm 0.09^{\mathrm{a}}$ & $6.78 \pm 0.02^{\mathrm{b}}$ & $6.78 \pm 0.01^{\mathrm{b}}$ \\
\hline NPOS (2.0) & $6.81 \pm 0.06^{\mathrm{a}}$ & $6.80 \pm 0.06^{\mathrm{a}}$ & $6.80 \pm 0.07^{\mathrm{a}}$ & $6.78 \pm 0.07^{\mathrm{b}}$ & $6.78 \pm 0.02^{\mathrm{b}}$ \\
\hline Zn-NPOS $(0.5)$ & $6.81 \pm 0.06^{\mathrm{a}}$ & $6.80 \pm 0.05^{\mathrm{a}}$ & $6.80 \pm 0.01^{\mathrm{a}}$ & $6.78 \pm 0.03^{\mathrm{b}}$ & $6.79 \pm 0.04^{\mathrm{b}}$ \\
\hline Zn-NPOS (1.0) & $6.81 \pm 0.03^{\mathrm{a}}$ & $6.81 \pm 0.07^{\mathrm{a}}$ & $6.80 \pm 0.08^{\mathrm{a}}$ & $6.78 \pm 0.04^{\mathrm{b}}$ & $6.78 \pm 0.03^{b}$ \\
\hline Zn-NPOS (1.5) & $6.81 \pm 0.02^{\mathrm{a}}$ & $6.80 \pm 0.07^{\mathrm{a}}$ & $6.80 \pm 0.04^{\mathrm{a}}$ & $6.78 \pm 0.09^{\mathrm{b}}$ & $6.78 \pm 0.02^{\mathrm{b}}$ \\
\hline Zn-NPOS (2.0) & $6.81 \pm 0.09^{\mathrm{a}}$ & $6.81 \pm 0.09^{\mathrm{a}}$ & $6.80 \pm 0.01^{\mathrm{a}}$ & $6.79 \pm 0.06^{\mathrm{b}}$ & $6.78 \pm 0.04^{b}$ \\
\hline
\end{tabular}

$\overline{\mathrm{a}, \mathrm{b}}$ Values within a row with different superscripts are significantly different $(P<0.05)$.

${ }^{1} \mathrm{POS}=$ powdered oyster shell, NPOS = nanopowdered oyster shell, Zn-NPOS = Zn-activated nanopowdered oyster shell. 
Table 2. Concentration of calcium $(\mathrm{mg} / 100 \mathrm{~mL}$; mean $\pm \mathrm{SD})$ of milk supplemented with dispersible nanopowdered oyster shell and stored at $4^{\circ} \mathrm{C}$ for $16 \mathrm{~d}$

\begin{tabular}{|c|c|c|c|c|c|}
\hline $\begin{array}{l}\text { Treatment }{ }^{1} \\
(\%, \mathrm{wt} / \mathrm{vol})\end{array}$ & \multicolumn{5}{|c|}{ Storage time } \\
\hline Control & $108.11 \pm 0.06^{\mathrm{e}}$ & $111.09 \pm 0.02^{\mathrm{e}}$ & $110.10 \pm 0.04^{\mathrm{e}}$ & $116.11 \pm 0.11^{\mathrm{e}}$ & $116.10 \pm 0.09^{\mathrm{e}}$ \\
\hline POS (1.0) & $515.11 \pm 0.12^{\mathrm{c}}$ & $512.19 \pm 0.17^{\mathrm{c}}$ & $514.10 \pm 0.04^{\mathrm{c}}$ & $517.00 \pm 0.19^{c}$ & $517.01 \pm 0.10^{\mathrm{c}}$ \\
\hline POS (1.5) & $698.01 \pm 0.41^{\mathrm{b}}$ & $693.21 \pm 0.35^{\mathrm{b}}$ & $696.11 \pm 0.33^{\mathrm{b}}$ & $700.00 \pm 0.23^{\mathrm{b}}$ & $697.00 \pm 0.11^{\mathrm{b}}$ \\
\hline POS $(2.0)$ & $931.00 \pm 0.35^{\mathrm{a}}$ & $924.22 \pm 0.86^{\mathrm{a}}$ & $935.00 \pm 0.54^{\mathrm{a}}$ & $929.16 \pm 0.04^{\mathrm{a}}$ & $930.05 \pm 1.03^{\mathrm{a}}$ \\
\hline NPOS (1.5) & $699.39 \pm 0.08^{\mathrm{b}}$ & $706.01 \pm 0.08^{\mathrm{b}}$ & $707.00 \pm 0.39^{\mathrm{b}}$ & $705.03 \pm 0.02^{\mathrm{b}}$ & $705.21 \pm 0.01^{\mathrm{b}}$ \\
\hline NPOS $(2.0)$ & $938.00 \pm 0.66^{\mathrm{a}}$ & $932.03 \pm 0.06^{\mathrm{a}}$ & $927.18 \pm 0.37^{\mathrm{a}}$ & $937.35 \pm 0.37^{\mathrm{a}}$ & $935.16 \pm 0.42^{\mathrm{a}}$ \\
\hline Zn-NPOS $(0.5)$ & $317.00 \pm 0.16^{\mathrm{d}}$ & $316.00 \pm 0.35^{\mathrm{d}}$ & $319.10 \pm 0.11^{\mathrm{d}}$ & $319.00 \pm 0.13^{\mathrm{d}}$ & $317.00 \pm 0.44^{\mathrm{d}}$ \\
\hline Zn-NPOS (1.0) & $514.13 \pm 0.39^{c}$ & $521.71 \pm 0.17^{\mathrm{c}}$ & $518.94 \pm 0.28^{\mathrm{c}}$ & $506.98 \pm 0.04^{c}$ & $518.00 \pm 0.13^{\mathrm{c}}$ \\
\hline Zn-NPOS $(1.5)$ & $709.20 \pm 6.22^{\mathrm{b}}$ & $708.03 \pm 0.47^{\mathrm{b}}$ & $699.14 \pm 0.04^{\mathrm{b}}$ & $700.00 \pm 0.19^{\mathrm{b}}$ & $702.10 \pm 0.22^{\mathrm{b}}$ \\
\hline Zn-NPOS $(2.0)$ & $940.00 \pm 0.39^{\mathrm{a}}$ & $938.03 \pm 0.29^{\mathrm{a}}$ & $936.11 \pm 0.61^{\mathrm{a}}$ & $940.08 \pm 0.76^{\mathrm{a}}$ & $938.27 \pm 0.54^{\mathrm{a}}$ \\
\hline
\end{tabular}

${ }^{\mathrm{a}-\mathrm{e}}$ Values within a treatment (row) with different superscripts are significantly different $(P<0.05)$ by Duncan's multiple range test.

${ }^{1} \mathrm{POS}=$ powdered oyster shell, NPOS $=$ nanopowdered oyster shell, Zn-NPOS = Zn-activated nanopowdered oyster shell.

and Beattie, 1997) and that of UHT milk was $-19 \mathrm{mV}$ (Gaucher et al., 2008), values that are in agreement with our control milk. On d 16, the zeta-potential values had decreased slightly, but those of milks with lower concentrations $(0.5 \%, \mathrm{vol} / \mathrm{vol})$ of NPOS and Zn-NPOS were -25 and $-26 \mathrm{mV}$, respectively. The zeta-potential values of milk with added POS were lower than those of the control. However, the zeta-potentials of the milks with high concentrations (1.5 and $2.0 \%, \mathrm{vol} / \mathrm{vol})$ of NPOS and Zn-NPOS were found to be similar to that of controls, and the low concentration samples (0.5 and $1.0 \%, \mathrm{vol} / \mathrm{vol}$ ) were shown to be more stable than the controls during storage. The decrease in zeta-potential could be affected by proteolysis, resulting in release of peptides containing negatively charged groups, such as glutamyl, aspartyl, phosphoseryl, and glycosidic residues of micelles during storage (Gastaldi et al., 2003; Crudden et al., 2005). In the current study, the zetapotential values of all samples decreased considerably during the 16-d storage period. However, throughout storage, the stability of the milks with added NPOS and Zn-NPOS remained higher than that of milk with added POS.

\section{Color}

Color changes of milks with added POS, NPOS, and Zn-NPOS were determined during storage at $4^{\circ} \mathrm{C}$ for $16 \mathrm{~d}$ (data not shown). The $\mathrm{L}$ and a values of milk supplemented with the dispersible powder solutions $(0.5-2.0 \%, \mathrm{vol} / \mathrm{vol})$ did not change significantly during storage $(P>0.05)$. According to Philips et al. (1995), the $\mathrm{L}$ value of milk has the most positive effect on consumer appeal. Thus, in the present study, we speculated that the addition of dispersible powder, at any concentration, would not negatively influence consumer appeal during the storage period $(16 \mathrm{~d})$ of the milk samples. However, regardless of treatment, the $\mathrm{b}$ values of all samples increased $(P<0.05)$ throughout the storage period. Similarly, Seo et al. (2011) reported that the $\mathrm{b}$ value of the nanopowdered chitosan-supplemented milk increased during a 15-d storage period. However, in the current study, the b values of all samples, including control, were similar throughout storage. Based on

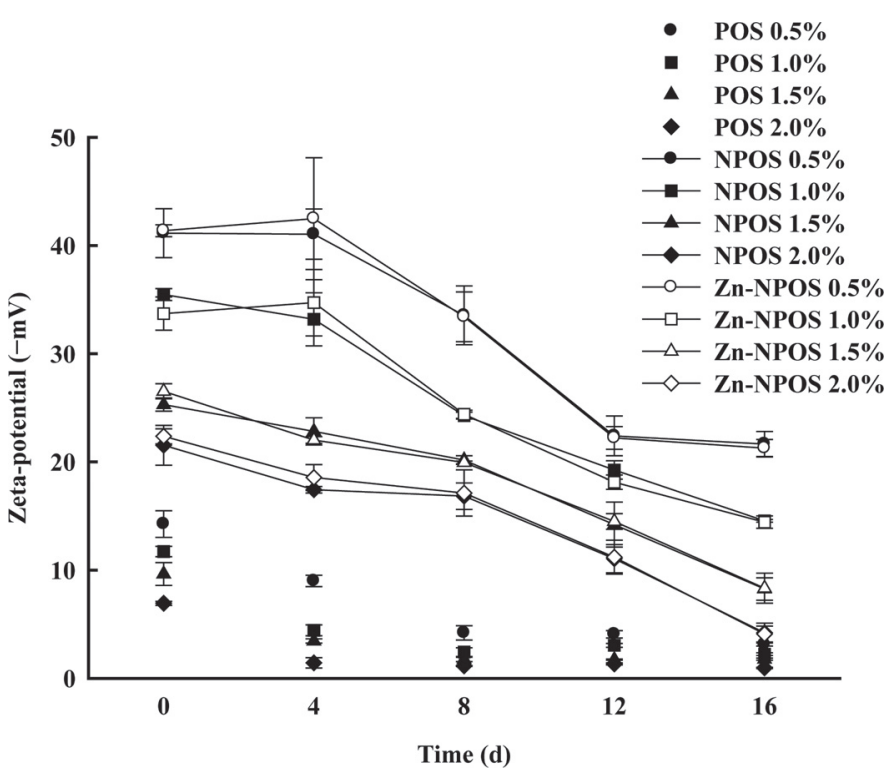

Figure 4. Change in zeta-potential of dispersible nanopowdered oyster shell-supplemented milk stored at $4^{\circ} \mathrm{C}$ for $16 \mathrm{~d}$. Sample values $=$ zeta potential of sample - zeta potential of commercial milk $(-21$ $\mathrm{mV})$. POS $=$ powdered oyster shell, NPOS $=$ nanopowdered oyster shell, Zn-NPOS = Zn-activated nanopowdered oyster shell. Error bars indicate standard deviations. 
Table 3. Sensory characteristics (mean \pm SD) of milk supplemented with dispersible nanopowdered oyster shell and stored at $4^{\circ} \mathrm{C}$ for $16 \mathrm{~d}$

\begin{tabular}{|c|c|c|c|}
\hline $\begin{array}{l}\text { Storage time and } \\
\text { treatment }^{1}(\%, \mathrm{wt} / \mathrm{vol})\end{array}$ & $\begin{array}{l}\text { Appearance: } \\
\text { Sedimentation }\end{array}$ & $\begin{array}{l}\text { Flavor: } \\
\text { Earthy }\end{array}$ & $\begin{array}{l}\text { Taste: } \\
\text { Bitterness }\end{array}$ \\
\hline \multicolumn{4}{|l|}{0 -d storage period } \\
\hline Control & $1.00 \pm 0.00^{\mathrm{d}}$ & $1.00 \pm 0.00^{\mathrm{c}}$ & $1.00 \pm 0.00^{\mathrm{b}}$ \\
\hline POS $(0.5)$ & $1.57 \pm 0.53^{\mathrm{c}}$ & $1.57 \pm 0.53^{\mathrm{ab}}$ & $1.14 \pm 0.38^{\mathrm{ab}}$ \\
\hline POS (1.0) & $2.29 \pm 0.49^{\mathrm{b}}$ & $1.86 \pm 0.69^{\mathrm{a}}$ & $1.29 \pm 0.49^{\mathrm{ab}}$ \\
\hline POS (1.5) & $2.57 \pm 0.53^{\mathrm{ab}}$ & $1.86 \pm 0.38^{\mathrm{a}}$ & $1.29 \pm 0.49^{\mathrm{ab}}$ \\
\hline POS $(2.0)$ & $2.71 \pm 0.49^{\mathrm{a}}$ & $1.86 \pm 0.38^{\mathrm{a}}$ & $1.43 \pm 0.53^{\mathrm{a}}$ \\
\hline $\operatorname{NPOS}(0.5)$ & $1.00 \pm 0.00^{\mathrm{d}}$ & $1.14 \pm 0.38^{\mathrm{bc}}$ & $1.00 \pm 0.00^{\mathrm{b}}$ \\
\hline NPOS (1.0) & $1.00 \pm 0.00^{\mathrm{d}}$ & $1.14 \pm 0.38^{b c}$ & $1.00 \pm 0.00^{\mathrm{b}}$ \\
\hline NPOS (1.5) & $1.14 \pm 0.38^{\mathrm{d}}$ & $1.29 \pm 0.49^{\mathrm{bc}}$ & $1.00 \pm 0.00^{\mathrm{b}}$ \\
\hline NPOS (2.0) & $1.14 \pm 0.38^{\mathrm{d}}$ & $1.29 \pm 0.49^{\mathrm{bc}}$ & $1.00 \pm 0.00^{\mathrm{b}}$ \\
\hline Zn-NPOS $(0.5)$ & $1.00 \pm 0.00^{\mathrm{d}}$ & $1.00 \pm 0.00^{\mathrm{c}}$ & $1.00 \pm 0.00^{\mathrm{b}}$ \\
\hline Zn-NPOS (1.0) & $1.00 \pm 0.00^{\mathrm{d}}$ & $1.00 \pm 0.00^{\mathrm{c}}$ & $1.00 \pm 0.00^{\mathrm{b}}$ \\
\hline Zn-NPOS (1.5) & $1.14 \pm 0.38^{\mathrm{d}}$ & $1.14 \pm 0.38^{\mathrm{bc}}$ & $1.29 \pm 0.49^{\mathrm{b}}$ \\
\hline Zn-NPOS $(2.0)$ & $1.14 \pm 0.38^{\mathrm{d}}$ & $1.14 \pm 0.38^{\mathrm{bc}}$ & $1.00 \pm 0.00^{\mathrm{b}}$ \\
\hline \multicolumn{4}{|l|}{$4 \mathrm{~d}$ of storage } \\
\hline Control & $1.00 \pm 0.00^{\mathrm{d}}$ & $1.00 \pm 0.00^{\mathrm{c}}$ & $1.00 \pm 0.00^{\mathrm{d}}$ \\
\hline POS $(0.5)$ & $2.29 \pm 0.49^{\mathrm{c}}$ & $2.14 \pm 0.38^{\mathrm{b}}$ & $1.29 \pm 0.49^{\mathrm{cd}}$ \\
\hline POS (1.0) & $3.00 \pm 0.58^{\mathrm{b}}$ & $2.29 \pm 0.76^{\mathrm{b}}$ & $1.57 \pm 0.53^{\mathrm{bc}}$ \\
\hline POS (1.5) & $3.29 \pm 0.49^{\mathrm{b}}$ & $2.57 \pm 0.79^{\mathrm{b}}$ & $1.86 \pm 0.69^{\mathrm{b}}$ \\
\hline POS (2.0) & $2.71 \pm 0.49^{\mathrm{a}}$ & $1.86 \pm 0.38^{\mathrm{a}}$ & $3.00 \pm 1.00^{\mathrm{a}}$ \\
\hline $\operatorname{NPOS}(0.5)$ & $1.00 \pm 0.00^{\mathrm{d}}$ & $1.14 \pm 0.38^{\mathrm{c}}$ & $1.00 \pm 0.00^{\mathrm{d}}$ \\
\hline NPOS (1.0) & $1.00 \pm 0.00^{\mathrm{d}}$ & $1.14 \pm 0.38^{\mathrm{c}}$ & $1.00 \pm 0.00^{\mathrm{d}}$ \\
\hline NPOS (1.5) & $1.14 \pm 0.38^{\mathrm{d}}$ & $1.43 \pm 0.53^{\mathrm{c}}$ & $1.00 \pm 0.00^{\mathrm{d}}$ \\
\hline NPOS (2.0) & $1.14 \pm 0.38^{\mathrm{d}}$ & $1.43 \pm 0.53^{\mathrm{c}}$ & $1.00 \pm 0.00^{\mathrm{d}}$ \\
\hline Zn-NPOS $(0.5)$ & $1.00 \pm 0.00^{\mathrm{d}}$ & $1.14 \pm 0.38^{\mathrm{c}}$ & $1.00 \pm 0.00^{\mathrm{d}}$ \\
\hline $\mathrm{Zn}-\mathrm{NPOS}(1.0)$ & $1.00 \pm 0.00^{\mathrm{d}}$ & $1.14 \pm 0.38^{\mathrm{c}}$ & $1.00 \pm 0.00^{\mathrm{d}}$ \\
\hline Zn-NPOS (1.5) & $1.14 \pm 0.38^{\mathrm{d}}$ & $1.29 \pm 0.49^{\mathrm{c}}$ & $1.00 \pm 0.00^{\mathrm{d}}$ \\
\hline Zn-NPOS $(2.0)$ & $1.14 \pm 0.38^{\mathrm{d}}$ & $1.29 \pm 0.49^{c}$ & $1.00 \pm 0.00^{\mathrm{d}}$ \\
\hline \multicolumn{4}{|l|}{$8 \mathrm{~d}$ of storage } \\
\hline Control & $1.00 \pm 0.00^{\mathrm{d}}$ & $1.00 \pm 0.00^{\mathrm{d}}$ & $1.00 \pm 0.00^{\mathrm{d}}$ \\
\hline POS (0.5) & $3.00 \pm 0.00^{\mathrm{c}}$ & $2.43 \pm 0.53^{\mathrm{c}}$ & $2.00 \pm 0.00^{\mathrm{c}}$ \\
\hline POS (1.0) & $3.57 \pm 0.53^{\mathrm{b}}$ & $2.86 \pm 0.90^{\mathrm{bc}}$ & $2.29 \pm 0.49^{\mathrm{b}}$ \\
\hline POS (1.5) & $4.43 \pm 0.53^{\mathrm{a}}$ & $3.29 \pm 0.49^{\mathrm{b}}$ & $2.43 \pm 0.53^{\mathrm{b}}$ \\
\hline POS (2.0) & $4.71 \pm 0.49^{\mathrm{a}}$ & $4.00 \pm 0.00^{\mathrm{a}}$ & $3.57 \pm 0.53^{\mathrm{a}}$ \\
\hline NPOS $(0.5)$ & $1.00 \pm 0.00^{\mathrm{d}}$ & $1.14 \pm 0.38^{\mathrm{d}}$ & $1.00 \pm 0.00^{\mathrm{d}}$ \\
\hline NPOS (1.0) & $1.00 \pm 0.00^{\mathrm{d}}$ & $1.14 \pm 0.38^{\mathrm{d}}$ & $1.00 \pm 0.00^{\mathrm{d}}$ \\
\hline NPOS (1.5) & $1.14 \pm 0.38^{\mathrm{d}}$ & $1.43 \pm 0.53^{\mathrm{d}}$ & $1.00 \pm 0.00^{\mathrm{d}}$ \\
\hline NPOS (2.0) & $1.14 \pm 0.38^{\mathrm{d}}$ & $1.43 \pm 0.53^{\mathrm{d}}$ & $1.00 \pm 0.00^{\mathrm{d}}$ \\
\hline Zn-NPOS $(0.5)$ & $1.00 \pm 0.00^{\mathrm{d}}$ & $1.14 \pm 0.38^{\mathrm{d}}$ & $1.00 \pm 0.00^{\mathrm{d}}$ \\
\hline Zn-NPOS (1.0) & $1.00 \pm 0.00^{\mathrm{d}}$ & $1.14 \pm 0.38^{\mathrm{d}}$ & $1.00 \pm 0.00^{\mathrm{d}}$ \\
\hline Zn-NPOS (1.5) & $1.14 \pm 0.38^{\mathrm{d}}$ & $1.29 \pm 0.49^{\mathrm{d}}$ & $1.00 \pm 0.00^{\mathrm{d}}$ \\
\hline Zn-NPOS $(2.0)$ & $1.14 \pm 0.38^{\mathrm{d}}$ & $1.29 \pm 0.49^{\mathrm{d}}$ & $1.00 \pm 0.00^{\mathrm{d}}$ \\
\hline \multicolumn{4}{|l|}{$12 \mathrm{~d}$ of storage } \\
\hline Control & $1.00 \pm 0.00^{\mathrm{e}}$ & $1.00 \pm 0.00^{\mathrm{d}}$ & $1.00 \pm 0.00^{\mathrm{d}}$ \\
\hline POS (0.5) & $3.86 \pm 0.38^{\mathrm{b}}$ & $3.43 \pm 0.53^{\mathrm{c}}$ & $3.00 \pm 0.00^{\mathrm{c}}$ \\
\hline POS (1.0) & $5.00 \pm 0.00^{\mathrm{a}}$ & $3.86 \pm 0.90^{\mathrm{bc}}$ & $3.29 \pm 0.49^{\mathrm{b}}$ \\
\hline POS (1.5) & $4.86 \pm 0.38^{\mathrm{a}}$ & $4.29 \pm 0.49^{\mathrm{b}}$ & $3.43 \pm 0.53^{\mathrm{b}}$ \\
\hline POS (2.0) & $5.00 \pm 0.00^{\mathrm{a}}$ & $5.00 \pm 0.00^{\mathrm{a}}$ & $4.57 \pm 0.53^{\mathrm{a}}$ \\
\hline $\operatorname{NPOS}(0.5)$ & $2.00 \pm 0.00^{\mathrm{d}}$ & $1.14 \pm 0.38^{\mathrm{d}}$ & $1.00 \pm 0.00^{\mathrm{d}}$ \\
\hline NPOS (1.0) & $2.00 \pm 0.00^{\mathrm{d}}$ & $1.14 \pm 0.38^{\mathrm{d}}$ & $1.00 \pm 0.00^{\mathrm{d}}$ \\
\hline NPOS (1.5) & $3.14 \pm 0.38^{\mathrm{c}}$ & $1.43 \pm 0.53^{\mathrm{d}}$ & $1.00 \pm 0.00^{\mathrm{d}}$ \\
\hline NPOS (2.0) & $3.43 \pm 0.53^{\mathrm{c}}$ & $1.43 \pm 0.53^{\mathrm{d}}$ & $1.00 \pm 0.00^{\mathrm{d}}$ \\
\hline Zn-NPOS $(0.5)$ & $2.00 \pm 0.00^{\mathrm{d}}$ & $1.14 \pm 0.38^{\mathrm{d}}$ & $1.00 \pm 0.00^{\mathrm{d}}$ \\
\hline Zn-NPOS (1.0) & $2.00 \pm 0.00^{\mathrm{d}}$ & $1.14 \pm 0.38^{\mathrm{d}}$ & $1.00 \pm 0.00^{\mathrm{d}}$ \\
\hline Zn-NPOS (1.5) & $3.14 \pm 0.38^{\mathrm{c}}$ & $1.29 \pm 0.49^{\mathrm{d}}$ & $1.00 \pm 0.00^{\mathrm{d}}$ \\
\hline Zn-NPOS $(2.0)$ & $3.43 \pm 0.53^{\mathrm{c}}$ & $1.29 \pm 0.49^{\mathrm{d}}$ & $1.00 \pm 0.00^{\mathrm{d}}$ \\
\hline \multicolumn{4}{|l|}{$16 \mathrm{~d}$ of storage } \\
\hline Control & $1.00 \pm 0.00^{\mathrm{e}}$ & $1.00 \pm 0.00^{\mathrm{b}}$ & $1.00 \pm 0.00^{\mathrm{d}}$ \\
\hline POS (0.5) & $4.43 \pm 0.53^{\mathrm{b}}$ & $4.57 \pm 0.53^{\mathrm{a}}$ & $4.00 \pm 0.00^{\mathrm{c}}$ \\
\hline POS (1.0) & $5.00 \pm 0.00^{\mathrm{a}}$ & $4.57 \pm 0.53^{\mathrm{a}}$ & $4.29 \pm 0.49^{\mathrm{b}}$ \\
\hline POS (1.5) & $5.00 \pm 0.00^{\mathrm{a}}$ & $5.00 \pm 0.00^{\mathrm{a}}$ & $4.43 \pm 0.53^{\mathrm{b}}$ \\
\hline POS (2.0) & $5.00 \pm 0.00^{\mathrm{a}}$ & $5.00 \pm 0.00^{\mathrm{a}}$ & $5.00 \pm 0.00^{\mathrm{a}}$ \\
\hline $\operatorname{NPOS}(0.5)$ & $3.00 \pm 0.00^{\mathrm{d}}$ & $1.14 \pm 0.38^{\mathrm{b}}$ & $1.00 \pm 0.00^{\mathrm{d}}$ \\
\hline NPOS (1.0) & $3.00 \pm 0.00^{\mathrm{d}}$ & $1.14 \pm 0.38^{\mathrm{b}}$ & $1.00 \pm 0.00^{\mathrm{d}}$ \\
\hline
\end{tabular}


Table 3 (Continued). Sensory characteristics (mean \pm SD) of milk supplemented with dispersible nanopowdered oyster shell and stored at $4^{\circ} \mathrm{C}$ for $16 \mathrm{~d}$

\begin{tabular}{lccc}
\hline $\begin{array}{l}\text { Storage time and } \\
\text { treatment }^{1}(\%, \mathrm{wt} / \mathrm{vol})\end{array}$ & $\begin{array}{c}\text { Appearance: } \\
\text { Sedimentation }\end{array}$ & $\begin{array}{c}\text { Flavor: } \\
\text { Earthy }\end{array}$ & $\begin{array}{c}\text { Taste: } \\
\text { Bitterness }\end{array}$ \\
\hline NPOS (1.5) & $4.00 \pm 0.00^{\mathrm{c}}$ & $1.43 \pm 0.53^{\mathrm{b}}$ & $1.00 \pm 0.00^{\mathrm{d}}$ \\
NPOS (2.0) & $4.43 \pm 0.53^{\mathrm{b}}$ & $1.43 \pm 0.53^{\mathrm{b}}$ & $1.00 \pm 0.00^{\mathrm{d}}$ \\
Zn-NPOS (0.5) & $3.00 \pm 0.00^{\mathrm{b}}$ & $1.14 \pm 0.38^{\mathrm{b}}$ & $1.00 \pm 0.00^{\mathrm{d}}$ \\
Zn-NPOS (1.0) & $3.00 \pm 0.00^{\mathrm{b}}$ & $1.14 \pm 0.38^{\mathrm{b}}$ & $1.00 \pm 0.00^{\mathrm{d}}$ \\
Zn-NPOS (1.5) & $3.86 \pm 0.38^{\mathrm{c}}$ & $1.29 \pm 0.49^{\mathrm{b}}$ & $1.00 \pm 0.00^{\mathrm{d}}$ \\
Zn-NPOS (2.0) & $4.43 \pm 0.53^{\mathrm{b}}$ & $1.29 \pm 0.49^{\mathrm{b}}$ & $1.00 \pm 0.00^{\mathrm{d}}$ \\
\hline
\end{tabular}

${ }^{\mathrm{a}-\mathrm{d}}$ Values within a column with different superscripts are significantly different $(P<0.05)$.

${ }^{1} \mathrm{POS}=$ powdered oyster shell, NPOS $=$ nanopowdered oyster shell, Zn-NPOS $=$ Zn-activated nanopowdered oyster shell.

these results, we suggest that the addition of dispersible NPOS or Zn-NPOS does not affect the color of milk.

\section{Sensory Evaluation}

The sensory properties of POS-, NPOS-, and ZnNPOS-supplemented milks at $4^{\circ} \mathrm{C}$ for $16 \mathrm{~d}$ are shown in Table 3. The sedimentation score (appearance) significantly increased in POS-supplemented milk when the concentration of POS increased $(P<0.05)$. However, NPOS- and Zn-NPOS-supplemented milks did not show sedimentation, regardless of concentration, until after $8 \mathrm{~d}$ of storage. Thereafter, sedimentation occurred in proportion to the concentration of powder added $(P<0.05)$. Singh et al. (2007) reported that regular calcium carbonate was sedimented on the bottom of milk early in storage. Earthy off-flavor of the POS-supplemented milk followed a similar trend to sedimentation; however, the milks supplemented with NPOS and Zn-NPOS did not score highly for earthy flavor during the storage period. The most distinguishable sensory score related to oyster shell powder was bitterness, which was significantly higher in the milk with added POS $(P<0.05)$. Bitterness increased significantly in POS-added milk during the storage period $(P<0.05)$. However, NPOS- and Zn-NPOS-supplemented milks were not significantly affected $(P>0.05)$. The dispersible nanochitosan (Seo et al., 2011) and nanopowdered peanut sprouts (Ahn et al., 2013) were also reported to not affect milk in terms of appearance, flavor, or taste. Based on the data obtained in this study, we suggest that supplementing milk with NPOS and Zn-NPOS at concentrations 0.5 and $1.0 \%$ (vol/vol) would be acceptable to consumers.

\section{CONCLUSIONS}

This study was designed to develop milk supplemented with dispersible NPOS or Zn-NPOS and to evaluate the changes in the physicochemical, dispersibility, and sensory properties of such milks during storage at $4^{\circ} \mathrm{C}$ for $16 \mathrm{~d}$. Optimal conditions for NPOS- and Zn-NPOS-supplemented milks were 0.5\% PGMS as the emulsifier and a mixing time of $24 \mathrm{~h}$. The stability of dispersible NPOS and Zn-NPOS under optimal conditions showed $-17.2 \mathrm{mV}$ zeta-potential of dispersibility. The data of $\mathrm{pH}$, zeta-potential of dispersibility, calcium concentration, color, and sensory analysis from this study confirmed that supplementing milk with NPOS or Zn-NPOS had no adverse effects on milk quality, and we conclude that NPOS and Zn-NPOS (0.5 and 1.0\%, wt/vol) could be used in calcium-supplemented milk.

\section{ACKNOWLEDGMENTS}

The present study was supported by a grant from Korea Institute of Planning and Evaluation for Technology in Food, Agriculture, Forestry and Fisheries (Gyeonggi-Do, Republic of Korea).

\section{REFERENCES}

Abbott, N. A., B. G. Coombe, and P. J. Williams. 1991. The contribution of hydrolyzed flavor precursors to quality differences in Shiraz juice and wines: An investigation by sensory descriptive analysis. Am. J. Enol. Vitic. 42:167-174.

Ahn, Y. J., P. Ganesan, and H. S. Kwak. 2013. Effect of nanopowdered peanut sprouts on physicochemical and sensory properties of milk. Korean J. Food Sci. Anim. Resour. 33:9-15.

Ajakaiya, J. O., and A. S. Leeson. 1997. Effects of calcium source, particle size and time on in vitro calcium solubility of some indigenous Nigerian mineral ingredients for poultry diets. Anim. Feed Sci. Technol. 65:293-298.

Ali, T., E. Numanoğlu, and İ. Saldaml. 2006. Proteolysis and storage stability of UHT milk produced in Turkey. Int. Dairy J. 16:633638.

Bonjour, J. P., and R. Rizzoli. 2001. Bone acquisition in adolescence. Pages 621-638 in Osteoporosis. 2nd ed. R. Marcus, D. Feldman, and J. Kelsey, ed. Academic Press, San Diego, CA.

Crudden, A., D. Afoufa-Bastien, P. F. Fox, G. Brisson, and A. L. Kelly. 2005. Effect of hydrolysis of casein by plasmin on the heat stability of milk. Int. Dairy J. 15:1017-1025.

Delgado, A. V., F. Gonzalez-Caballero, R. J. Hunter, L. K. Koopal, and J. Lyklema. 2005. Measurement and interpretation of electro kinetic phenomena (IUPAC technical report). Pure Appl. Chem. 77:1753-1805. 
Drake, M. A. 2007. Invited review: Sensory analysis of dairy foods. J. Dairy Sci. 90:4925-4937.

Duplat, D., A. Chabadel, M. Gallet, S. Berland, L. Bedouet, M. Rousseau, S. Kamel, C. Milet, P. Jurdic, and M. Brazier. 2007. The in vitro osteoclastic degradation of nacre. Biomaterials 28:21552162.

European Commission. 2008. Directive 2008/100/EC amending council directive 90/496/EEC on nutrition labelling for foodstuffs as regards recommended daily allowances, energy conversion factors and definitions. Off. J. L 285:9-12.

Gastaldi, E., N. Trial, C. Guillaume, E. Bourret, N. Gontard, and J. L. Cuq. 2003. Effects of controlled $\kappa$-casein hydrolysis on rheological properties of acid milk gels. J. Dairy Sci. 86:704-711.

Gaucher, I., D. Molle, V. Gagnaire, and F. Gaucheron. 2008. Effects of storage temperature on physic-chemical characteristics of semiskimmed UHT-milk. Food Hydrocoll. 22:130-143.

Hanaor, D. A. H., M. Michelazzi, C. Leonelli, and C. C. Sorrell. 2012. The effects of carboxylic acid on the aqueous dispersion and electrophoretic deposition of $\mathrm{ZrO}_{2}$. J. Eur. Ceram. Soc. 32:235-244.

Hilty, F. M., J. T. N. Knijenjeburg, A. Teleki, F. Krumeich, R. F. Hurrell, S. E. Pratsinis, and M. B. Zimmermann. 2011. Incorporation of $\mathrm{Mg}$ and $\mathrm{Ca}$ into nanostructured $\mathrm{Fe}_{2} \mathrm{O}_{3}$ improves Fe solubility in dilute acid and sensory characteristics in foods. J. Food Sci. $76: \mathrm{N} 2-10$.

Huang, S., J. Ching, C. W. Hsu, and W. H. Chang. 2009. Effects of nano calcium carbonate and nano calcium citrate on toxicity in ICR mice and on bone mineral density in an ovariectomized mice model. Nanotechnology 20:375102.

Institute of Medicine (IOM). 2010. Dietary reference intakes: Recommended intakes for individuals. IOM, National Acad. Press, Washington, DC.

Kansal, V. K., and S. Chaudhary. 1982. Biological availability of calcium, phosphorous and magnesium from dairy products. Milchwissenschaft. 37:261-263.

Karraker, K. A., and C. J. Radke. 2002. Disjoining pressures, zeta potentials and surface tensions of aqueous non-ionic surfactant/ electrolyte solutions: Theory and comparison to experiment. Adv. Colloid Interface Sci. 96:231-264.

Kaushik, R., B. Sachdeva, S. Arora, S. Kapila, and B. K. Wadhwa. 2014. Bioavailability of vitamin $\mathrm{D}_{2}$ and calcium from fortified milk. Food Chem. 147:307-311.

Kruger, M. C., J. C. Christine, L. M. Schollum, B. Kuhn-Sherlock, and M. J. Shearer. 2006. Effect of calcium fortified milk supplementation with or without vitamin $\mathrm{K}$ on biochemical markers of bone turnover in premenopausal women. Nutrition 22:1120-1128.

Kwak, H. S. 2014. Methodologies used for the characterization of nano- and microcapsules. Pages $82-83$ in Nano- and Microencapsulation for Foods. M. H. Nguyen, N. F. K. Aripin, X. G. Chen, and H. J. Park, ed. Wiley Blackwell, Ames, IA

Lamghari, M., M. J. Almeida, S. Berland, H. Huet, A. Laurent, C. Milet, and E. Lopez. 1999. Stimulation of bone marrow cells and bone formation by nacre: In vivo and in vitro studies. Bone 25:91S$94 \mathrm{~S}$

Lee, S. J., J. H. Hwang, S. H. Kim, S. G. Min, and H. S. Kwak. 2006. Comparison of the physicochemical properties of freeze-concentrated versus evaporated milk. Food Sci. Biotechnol. 15:844-850.
Nakahara, Y., N. Mizuguchi, and K. I. Miyata. 1978. Effects of surfactants on $\mathrm{CaCO}_{3}$ spheres prepared by interfacial reaction method. J. Colloid Interface Sci. 68:401-407.

On-Nom, N., A. S. Grandison, and M. J. Lewis. 2012. Heat stability of milk supplemented with calcium chloride. J. Dairy Sci. 95:1623-1631.

Park, J. W., S. R. Bae, J. Y. Suh, D. H. Lee, S. H. Kim, H. J. Kim, and C. S. Lee. 2008. Evaluation of bone healing with eggshell-derived bone graft substitutes in rat caldaria: A pilot study. J. Biomed. Mater. Res. 87A:203-214

Park, M. J., J. W. Ahn, and H. Kim. 2001. Study on the dispersion stability of precipitated calcium carbonate suspensions. J. Korean Ceramic Soc. 38:343-350.

Pays, K., J. Giermanska-Kahn, P. Pouligny, J. Bibette, and F. LealCalderon. 2001. Double emulsions: A tool for probing thin film metastability. Phys. Rev. Lett. 87:178304.

Philips, L. G., M. L. McGrief, D. M. Barbano, and H. A. Lawless. 1995. The influence of fat on the sensory properties, viscosity polymers: Chemistry, solubility and fiber formation. Prog. Polym. Sci. 34:641-678.

Rasenack, N., and B. W. Muller. 2004. Micron-size drug particles: Common and novel micronization techniques. Pharm. Dev. Technol. 9:1-13.

Rizzoli, G. 2008. Nutrition: Its role in bone health best practices. J. Clin. Endocrinol. Metab. 22:813-829.

Sahoo, S. K., J. Panyam, S. Prabha, and V. Labhasetwar. 2002. Residual polyvinyl alcohol associated with poly (D, L-lactide-co-glycolide) nanoparticles affects their physical properties and cellular uptake. J. Control. Release 82:105-114.

Seo, M. H., Y. H. Chang, S. Lee, and H. S. Kwak. 2011. The physicochemical and sensory properties of milk supplemented with ascorbic acid-soluble nano chitosan during storage. Int. J. Dairy Technol. 64:57-63.

Singh, G., S. Arora, G. S. Sharma, J. S. Sindhu, V. K. Kansal, and R. B. Sangwan. 2007. Heat stability and calcium bioavailability of calcium-fortified milk. Lebenson. Wiss. Technol. 40:625-631.

SAS Institute. 2001. SAS User's Guide: Statistics. Version 9.0 ed. SAS Inst. Inc., Cary, NC.

Wade, T., and J. K. Beattie. 1997. Electroacoustic determination of size and zeta potential of fat globules in milk and cream emulsions. Colloids Surf. B Biointerfaces 10:73-85.

Wheeler, A. P., K. W. Rusenko, D. M. Swift, and C. S. Sikes. 1988. Regulation of in vitro and in vivo $\mathrm{CaCO}_{3}$ crystallization by fractions of oyster shell organic matrix. Mar. Biol. 98:71-80.

Wong, N. P., and D. E. Lacroix. 1980. Biological availability of calcium in dietary products. Nutr. Rep. Int. 21:673-680.

$\mathrm{Xu}$, R. 2002. Electrophoretic light scattering. Pages 289-343 in Particle Characterization: Light Scattering Methods. Kluwer Academic Publishers, London, UK.

Yang, Y., Q. Yao, X. Pu, Z. Hou, and Q. Zhang. 2011. Biphasic calcium phosphate macroporous scaffolds derived from oyster shells for bone tissue engineering. Chem. Eng. J. 173:837-845.

Yoo, S. H., S. B. Kang, J. H. Park, K. S. Lee, J. M. Kim, and S. S. Yoon. 2013. Effect of heat-treat methods on the soluble calcium levels in the commercial milk products. Korean J. Food Sci. Anim. Resour. 33:269-276. 